\title{
Preface to Special Issue of Numen on Asceticism in the Qur'an
}

\author{
Anders Klostergaard Petersen
}

What does Islam have to do with asceticism? The question is far from unequivocal, since the answer is ambiguous, to say the least. On the one hand, there are clearly traces of asceticism in the Qur'an involving a world-renouncing stance and elements relating to self-privation. On the other hand, the Qur'an reflects a far more lenient attitude toward ascetic practices, when compared to, for instance, contemporaneous Syrian Christianity. Believers should enjoy the God-given blessings of the natural world and refrain from becoming religious overdoers. This special issue of Numen deals with asceticism in the context of formative Islam.

The idea behind this issue came up some years ago. At the Department for the Study of Religion at Aarhus University, we occasionally have joint collegial readings of new monographs. A particularly fruitful discussion came out of our common reading of Peter Sloterdijk's Du mußt dein Leben ändern (2009), which gave rise to several new ideas regarding asceticism. Sloterdijk's key argument, that askēsis should be understood in its basic Greek meaning of training, resonated especially well with the thinking of several colleagues who represent a variety of different fields in the history of religion. They found it not only obvious but also thought-provoking to relate such an understanding to the diversity of ascetic practices permeating the empirical fields with which they were especially acquainted. We decided to devote a special seminar to the theme and to publish the most readable and interesting articles in Religionsvidenskabeligt Tidsskrift - a journal in the study of religion in the Scandinavian languages, located at our department. A special issue (no. 64) of the journal was published in 2016. However, I found it obvious also to present some of our research results to colleagues outside a Scandinavian-language context and, thereby, to see if others would engage in some of the ideas we had been discussing. At the XXI IAHR World Conference held in Erfurt in August 2015 we had a special panel devoted to the theme. It included three sessions with speakers from Aarhus, as well as a number of international colleagues, such as Professor Einar Thomassen and Professor Merlin Donald, who hold honorary chairs in 
our department and on various occasions have taken part in our ongoing discussions of asceticism.

In connection with my own engagement in the Enoch and Nangeroni seminars directed by Professor Gabriele Boccaccini, in which the study of formative Islam has recently been included as a separate field of discussion, I found it important to include early Islam in the discussions of asceticism. The more so, since the Qur'an and early Islam hardly figure in standard works on asceticism. Therefore, it was worthwhile to analyze the Qur'an in light of our general research on asceticism and see what could be gained by this examination. At the same time, such an examination would benefit the further integration of the study of early Islam into the general field of comparative religion as well as into the history of religion, in which formative Islam unfortunately does not feature as prominently as it ought to do. The more we expose the study of early Islam to the types of historical criticism with which we have been acquainted in biblical scholarship for more than a century, the better. Ultimately, this will, I hope, lead to a full inclusion of the study of early Islam in the wider context of comparative religion and the history of religions. With this aim in mind, I organized two seminars at Aarhus University in which leading scholars of formative Islam, such as Carlos Segovia, Guillaume Dye, Michael Bonner, and Emilio Gonzalez-Ferrin, took part, together with colleagues from the general study of the history of religion: Ingvild Sælid Gilhus, Laura Feldt, Roberto Alciati, Einar Thomassen, and Jan N. Bremmer.

Following these symposia and the stimulating conversations that occurred during them, we here present the rewritten papers on asceticism in the Qur'an, together with a more basic theoretical article on the phenomenon, presenting some of the general ideas that evolved during our discussions in Aarhus. Our basic idea is to use these reflections as a lens through which asceticism in the Qur'an may be examined. Thereby, we also use the studies of the Qur'an to broaden and possibly refine the theoretical grasp on asceticism, and to present these studies in the general context of the study of religion and of the history of religion. Numen was an obvious choice for this presentation.

In addition to the articles brought to bear on asceticism in the context of the Qur'an, this issue begins with a more extensive theoretical work dealing with asceticism in the history of scholarship as well as in the current debate. Going back to two classics in scholarship on asceticism, Émile Durkheim's Les formes élémentaires de la vie religieuse (1912) and Max Weber's Zwischenbetrachtung from Die Wirtschaftsethik der Weltreligionen (1920), I argue that many of the problems haunting the contemporary discussion of the topic can be overcome if we rethink these two markedly different understandings and bring them together in a grander narrative that recounts the entire history of asceticism. 
Whereas the Weberian understanding relates to those forms of asceticism that emerged with the appearance of Axial Age types of religion around the middle of the first millennium BCE, the Durkheimian concept of asceticism has a more general character and sees asceticism as integral to all forms of human culture and social groups. To become part of a group, the individual has to renounce his or her special needs and desires for the benefit of the group. Our entire educational system from the earliest forms of childcare to the university exemplifies this form of asceticism. Whether we are small children or adults partaking in learned seminars, it takes considerable effort and social skills to remain quiet and listen to what others try to convey to us. The inculcation and embracing of the need to let go of one's own desires in favor of the group is ultimately what lies at the core of asceticism. In Durkheim's view, this is the most fundamental form of asceticism and is accordingly ubiquitous to human sociality, since it revolves around the basic conflict between self and collectivity. Therefore, this type of asceticism is also culturally affirmative, since it confirms the existing culture and collectivity at the cost of the individual. Corollary with this type of asceticism is a special one reserved for the few, who like shamans, undergo particular privations for the sake of affirming the basic ideals, norms, and values of the group. This form of asceticism is also culturally affirmative since it buttresses the general culture and primes the many to strengthen group affiliation and consent to fundamental collective ideals and norms. In addition to this Durkheimian understanding of two types of asceticism is a third, which is perceptively captured by Weber. This is a countercultural form, which does not mean that it evades culture; the point is that it is counter-cultural toward the ordinary culture from which the ascetics secede in order to create another and better culture. Integral to the emergence of kosmos religions or Axial Age religions, this type of asceticism reframes one's entire life into a program of training aimed to liberate one from the fetters of this life. This is exactly the point at which the Weberian understanding converges with the idea of asceticism as a training program so elegantly elaborated upon by Peter Sloterdijk in close continuity with Weber. Therefore, Sloterdijk also does not constrain asceticism to a matter of religion only. He extends it to cover phenomena like sports, arts, and entertainment - areas to which religious exercise has become disseminated, which used to be part of religion, but with modernity have evolved into independent cultural realms.

The Sloterdijkian understanding has inspired the following articles by Mortensen, Bonner, and Christiansen. Mortensen discusses asceticism in the Qur'an through the Sloterdijkian and Weberian lens. Contrary to what has often been said about asceticism in the Qur'an, Mortensen holds that strong ascetic features can, in fact, be seen, especially if one acknowledges that the 
striving for perfection takes on a spatial and horizontal character. By means of spatial metaphors, believers are continuously inculcated to secede from ordinary culture. This is the asceticism delineated by Weber and according to which the aim for perfection takes the form of withdrawal from ordinary culture. At the same time, secession from ordinary culture becomes a matter of continuous training. The negative stance toward the ordinary culture is counteracted in the later Islamic exegetical tradition reinterpreting the secession in light of "stationary piety." After all, to endure and grow, any religion has to make compromises with the surrounding culture. A dire ideology of opposition runs counter to the aspiration to grow and persist.

Parallel to Mortensen, Michael Bonner takes his point of departure in the Sloterdijkian understanding. Although the Qur'an points to fasts and vigils, it does not insist on them but represents, not least compared to contemporaneous forms of Christianity, a far more moderate politics of asceticism with perhaps a greater acknowledgment of the difficulties involved in enforcing a politics of secessionist asceticism. Yet when seen in the light of a training program, the Qur'an certainly exemplifies an ascetic disposition. Hijra in the sense of an ongoing attitude of separation and exile testifies to some of the same elements as pointed out in Mortensen's article. So does the idea of jihad in the sense of training for and engaging in combat. Similarly, the call for poverty as a heroic form of benefaction supports the idea of seeing important strands in the Quran in light of asceticism. However, how should one contextualize such a training program in the Qur'anic milieu? Focusing on poverty and generosity, Bonner uses Weil and Nöldeke not to construe a chronology of the Qur'an but to tease out different communities of reception. This is another way of taking inspiration from the theme of asceticism to cast new light on the complicated issue of the formation of the Qur'an and its multiple milieus of reception.

Similarly to Mortensen's article, Christiansen argues that if we define asceticism in the prevalent and narrow understanding of renunciation, selfdenial, and self-privation, the Qur'an does not abound with ascetic elements. However, if we conceive of asceticism in light of Sloterdijk's understanding of it as constituting a training program, things begin to look very different. If we approach the Qur'an on the background of asceticism as a comprehensive cultural phenomenon (Durkheim's first type of asceticism), we see how the Qur'an becomes a text permeated by ascetic values and norms. The Qur'an embodies an education project aimed to prime its addressees to think and behave in a distinct way, complying with the overall ideology of the Qur'an. Based on four key examples, Christiansen demonstrates how the Qur'an conforms to other post-axial forms of religion by construing an ascetic, deliberate, and selfreflexive mental training program for its adherents. 
In the final article, Dye shows the continued importance of redaction history and demonstrates how we may advantageously use this method in in-depth textual studies of the Qur'an. Based on careful analysis of two Qur'anic parallels, Q23:1-11 and Q70:22-35, Dye argues that through a complicated history of rewriting these two texts of instruction underwent a considerable change in meaning. At first they called their addressees to a pious and ascetic life, but through a process of rewriting, and thus reinterpretation, they came to tone down the original strong injunction to a life in continence. Parallel to Bonner's article, Dye substantiates how careful textual studies of Qur'anic asceticism may also be used to illuminate the background and development of the Quran and early Islamic piety.

We hope that this collection of articles will not only contribute to the ongoing discussions about asceticism as a ubiquitous element in the history of religion, but also that it will lead to a greater inclusion of studies on early Islam into the wider scientifically founded comparative study of religion. Whether in the form of asceticism of the first or second Durkheimian type or as the Weberian third type, asceticism is an inevitable phenomenon in human culture and sociality, since it impinges on the fundamental relationship between self and group, individual and collectivity. Additionally, we hope that the inclusion of the Sloterdijkian take on asceticism as a basic training program integral to human culture since the emergence of kosmos religions may encourage new research on asceticism. As is evident from the articles here, we have taken much inspiration from this way of looking at askēsis and asceticism. Finally, we hope that the juxtaposition of asceticism and formative Islam has not only enhanced our understanding of the Qur'an but also will contribute to the inclusion of early Islam in future studies of asceticism. When taken in the traditional sense of self-privation and renunciation, asceticism in the Qur'an may not be the most obvious choice of study. Yet when seen in the wider context of a training program, it is obvious to add studies of the Qur'an to other more time-honored fields of studies on asceticism. Additionally, such an approach allows us to include a variety of other examples and fields. However, we leave it to others to embark on such studies.

In the very last phase of the editing of this special issue of Numen, we learned that our cherished colleague Michael Bonner had suddenly died at a relatively young age on May 24 (1952-2019). Michael was an erudite and popular Professor of Islamic History at the Department of Middle East Studies and a Professor of History at the College of Literature, Science, and the Arts at the University of Michigan. He served this department for more than thirty years. Anyone familiar with Michael was struck by his amicability, generosity, and 
polyhistorian nature, with a breadth of interests and skills, such as being also a gifted musician. One could hardly think of a better colleague with whom to discuss new ideas. His many monographs and articles pay witness to an eminent scholar whose significance in pushing the study of early Islam into the wider context of the scientifically grounded comparative study of the history of religions will be difficult to replace. As a small token of Michael's scholarly importance and the indelible impression he made on those of us who had the privilege to know him and collaborate with him, we dedicate this issue on asceticism in formative Islam to his memory. 